E3S Web of Conferences 1, 24003 (2013)

DOI: $10.1051 / \mathrm{e} 3$ sconf/20130124003

C Owned by the authors, published by EDP Sciences, 2013

\title{
Total Mercury in Lake Neusiedl, Austria
}

\author{
$\underline{\text { F. Jirsa }}^{1}$, D. Pirker ${ }^{1}$ and R. Krachler ${ }^{1}$ \\ ${ }^{1}$ University of Vienna, Institute of Inorganic Chemistry, Waehringer Strasse 42, 1090 Vienna, Austria, \\ franz.jirsa@univie.ac.at
}

\begin{abstract}
Between May and September 2011 a total of 361 samples from water, sediment, macrophytes and fish tissues from the shallow, slightly alkaline Lake Neusiedl were measured for their total mercury content with cold vapour atomic absorption spectroscopy (CV-AAS). Hg content of surface water was below the LOD of $0.1 \mu \mathrm{g} / \mathrm{L}$ and the sediments displayed contents between 0.025 and $0.113 \mu \mathrm{g} / \mathrm{g} \mathrm{dw}$, significantly correlated with the proportion of organic components (fig 1). Although these results do not point to an anthropogenic pollution of the lake, considerable amounts of mercury could be measured in fish samples and macrophytes. Both investigated submerged plant species, namely Potamogeton pectinatus and Myriophyllum spicatum show a high potential for bioaccumulation of $\mathrm{Hg}$, presenting mean values of $0.245 \pm 0.152$ and $0.298 \pm 0.115$ $\mu \mathrm{g} / \mathrm{g} \mathrm{dw}$ respectively. Compared to freshwater fish from other unpolluted sites high amounts of $\mathrm{Hg}$ could be measured (fig. 2). Biomagnification and significant differences could be observed when comparing muscle samples of the planctivorous fish species rudd Scardinus erythrophthalmus $(\mathrm{n}=10$, mean $=0.084 \mu \mathrm{g} / \mathrm{g} \mathrm{ww})$ with the piscivorous perch Perca fluviatilis $(\mathrm{n}=21$, mean $=0.184 \mu \mathrm{g} / \mathrm{g}$ ww) or pike-perch Sander lucioperca $(\mathrm{n}=9$, mean $=0.205 \mu \mathrm{g} / \mathrm{g}$ ww) respectively. Significantly lower values were measured in the muscle of the piscivorous pike Esox lucius $(\mathrm{n}=25$, mean $=0.135 \mu \mathrm{g} / \mathrm{g} \mathrm{ww})$ in which a strong correlation between fish age and $\mathrm{Hg}$ content did not occur. In addition the muscle/liver ratio of $\mathrm{Hg}$ in pike was significantly lower compared to the other fish species, which points to a different $\mathrm{Hg}$ metabolism in pike, maybe under the specific saline alkaline conditions of this lake.
\end{abstract}

Key words: total mercury, bioaccumulation, bioindication, freshwater fish, submerged waterplants

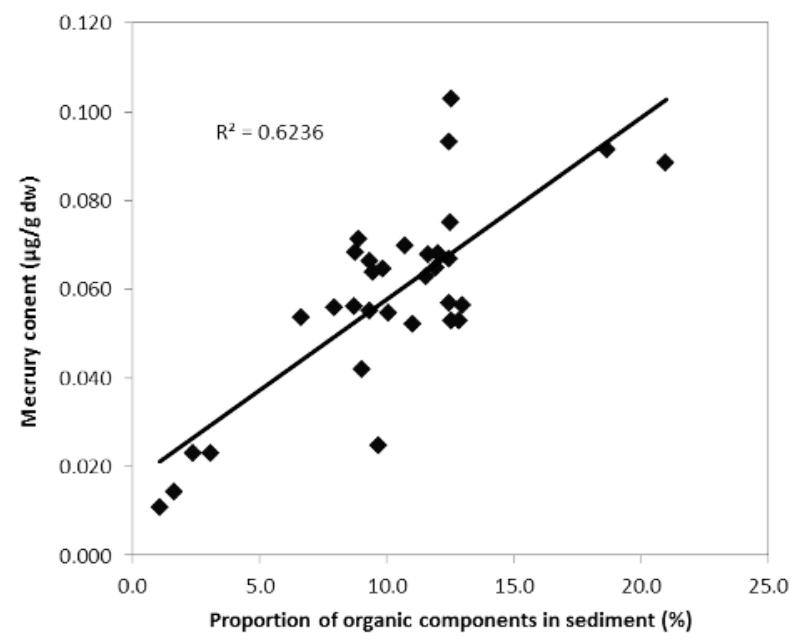

Fig. 1. Correlation of total mercury and organic components in sediments of Lake Neusiedl. 


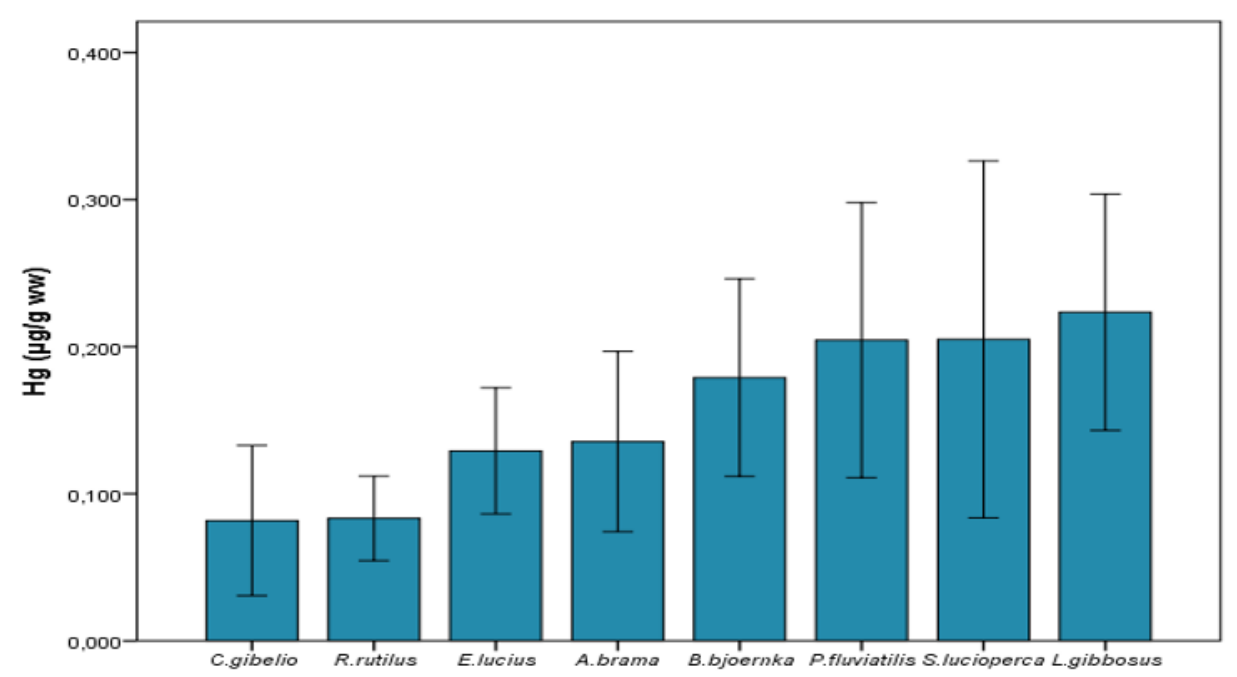

Fig. 2. Total mercury in muscle of different fish species from Lake Neusiedl. 